\title{
THE MECHANICS OF THE INSTALMENT CREDIT SALE
}

\author{
M. WirLiam Aderson*
}

The modern instalment credit sale may be justly compared to an intricate piece of machinery. Its legal structure is composed in part of legal rules, in part of contractual provisions. But a study of the machine's design will not suffice to reveal its everyday operation, for legal devices contain many tools intended only for emergency use. For an understanding of the operation of the mechanism which has been created for instalment sale credit, it is necessary to examine it with reference to the business practices which have developed in its employment. This article, accordingly, seeks to depict not only the legal structure of the instalment credit sale but also its operation, chiefly as it is revealed in the retail sale of automobiles. ${ }^{1}$ The diversity in both the fields of law and practice ${ }^{2}$ is such that generalization has been compelled, with the consequent sacrifice of those qualifications essential to complete accuracy. Detailed portrayal, however, would require a corpulent treatise.

Instalment selling in the average retail sale where the seller himself assumes the burden of carrying the credit is characterized by relatively simple agreements ${ }^{3}$ usually

- A.B., 1932, Washington and Lee University. Member of the Virginia Bar. Now a member of the third year class in the Duke University School of Law and Current Decisions Editor of the Duke Bar Associotion Journal.

${ }^{2}$ The retailing of automobiles has been selected in part because the volume of automobile sales on instalment credit constitutes, it has been estimated, over 50 per cent of all retail instalment sales, Lynd, The People as Consumets, 2 Recent Socinl Trends (1933) 857, 862, and in part because the legal mechanism seems to have been most completely developed in this field. Concentration on the normal automobile transaction has eliminated the consideration of those abuses which are encountered most frequently in the sale of other commodities. For a discussion of sharp practices encountered in instalment credit sales, see Greene, Better Business Bureau Activities in Aid of the Time Purchaser, infra, p. 254.

Considerations of space have precluded a treatment of the credit mechanism created for automobile wholesaling.

2A business national in scope will undoubtedly reveal variation in practices not only from region to region but also from company to company. As representative of the contracts of the standard, reputable finance company, contracts used by the four national companies, Commercial Credit Company, Commercial Invest Trust, Inc., General Motors Acceptance Corporation, and Universal Credit Cumpany, have been selected for study. Although one set of contracts covering the nation was secured, most of those examined were prepared for use in North Carolina and adjacent states. Study of the contracts was supplemented by interviews with dealers and finance company representatives and referenee to the works hereinafter cited.

${ }^{3}$ These more simply phrased contracts, as used by companies doing their own financing to a large extent, such as Montgomery Ward and Sears, Roebuck, have apparently proved to be about as effective for their purposes as the more elaborate finance company contract. The smaller sums usually involved, 
designated as "Easy Payment Plan," "Ten Payment Plan," "Nu-Way Credit," or merely "Conditional Sale Contract." These contracts do little more than provide for retention of title in the seller with a stipulation reciting that a down payment of a certain amount has been made on the purchase, with remainder of the price to be paid in monthly or weekly instalments generally ranging from 25 cents to ten dollars. But a rise in the amount of the credit extended presents a problem of financing for seller as well as purchaser and leads to the employment of more elaborate credit instruments, as is best evidenced in the retail sale and financing of automobiles. The large capital necessary for extensive financing in this field necessitates a selling of the purchaser's debt to someone who will pay the dealer cash and continue unaltered the credit extended to the purchaser. To meet this need, a new business institution has been developed, the sales finance company. For its operations, the finance company requires the embodiment of the car purchaser's debt in a negotiable note which may be readily discounted and rediscounted and which may be enforced with a minimum of inconvenience. The sale of a debt which is evidenced merely by a simple contract of sale and title-retaining instrument is difficult, for a non-negotiable contract of this character presents an enhanced credit risk and is one of the least acceptable forms of commercial paper.

The finance company could not long have survived had it relied on the initiative and ingenuity of the local dealer and his counsel to supply appropriate credit instruments and information. Consequently, it is the finance company which not only normally determines the credit terms to be extended to the purchaser but also supplies the credit instruments and personal information forms embodying his obligation and revealing his credit reputation.

Today the purchaser of an automobile on the instalment plan, after agreeing on terms $s^{4}$ and filling out a "purchaser's statement,"5 signs an elaborate contract providing for retention of title to the car in the seller and setting forth in full the obligation of the buyer to pay. There are additional stipulations as to conditions of the buyer's use of the car and rights of the seller upon default by the buyer in payment of the price or non-observance of the conditions. Attached to or accompanying this contract

together with the willingness to make extensions, may in part account for the relative infrequency of appearance of these two companies in appellate courts.

"The ordinary practice is to sell new cars for one-third down payment with the remainder payable in twelve months, eighteen being the limit. On used cars, minimum down payments are around forty per cent of the total price, with balance payable at the longest in twelve months, since expericnce has shown that the used car buyer and the used car itself present a greater financing risk. Golieb, Credit and ColLECTIONS (193I) 69. For school teachers, farmers, and others with periodic incomes, plans deferring payment during the non-incom= months are arranged.

- The back of the original copy of the contract bears a form questionnaire for information relative to the purchaser's backiground, earning power, and general financial standing. The experience of the merchants who have extended credit to the purchaser, as revealed through credit bureaus, coupled with the nature and stability of the purchaser's employment, in large measure determine acceptance or rejection as a credit risk. In doubtful cases, careful personal investigation is made by a company representative. Credit men reiterate that the main question is, "Can he and will he pay?" See, in general, GrImes, Financinc Automobile Sales (I926) 42. 
is a promissory negotiable note; which is signed by the purchaser as maker and indorsed on the back of the dealer, either with or without recourse, depending on the nature of his agreement with the finance company. This note, accompanied by an assignment of the conditional sales contract, is then sent to the finance company for purchase.

\section{The Dealer and Finance Company}

If the finance company, after an investigation of the credit risk entailed, decides to purchase the note and contract offered it, the company will remit ${ }^{6}$ to the dealer an amount equal to the difference between the cash selling price of the car and the down payment which he has retained. The remainder of the sum due on the note represents the financing charge. ${ }^{7}$ To what extent the dealer then steps out of the picture rests wholly on which one of the three types of finance agreements he is working under-recourse, non-recourse, or repurchase. ${ }^{8}$ An examination of these types of dealer-finance company relationships is an essential preliminary to the consideration of the operation of the purchaser's contract.

\section{r. The Recourse Plan}

The dealer indorses the note with recourse, and if the purchaser fails to pay, the dealer is liable on the note for the balance due. In the early days of large scale instalment financing this was the practically universal requirement. Today it has virtually disappeared in automobile financing, except in the few cases where a bank or small loan company extends the credit. ${ }^{2}$ The insistent demand by the dealers for relief from the constant menace to their liquidity arising out of their contingent liability in the event of default by the buyer or of loss or destruction of the car, led to the advancement of two other plans of financing, the non-recourse indorsement and the repurchase plan.

However, the finance companies do insist on indorsement with recourse in the financing of domestic appliances, e.g., refrigerators, oil burners, electric stoves, vacuum

${ }^{6}$ Generally the finance company must accept or reject the paper within 20 days. According to the financial standing and general reputation of the dealer for selecting good credit risks, the dealer is either paid by draft on the finance company as soon as the paper is mailed to it, or by check after the paper has been accepted. In the former case, the dealer agrees either to repurchase or indorse with recourse all paper which is rejected as below the credit requirement.

${ }^{7}$ Some companies remit a portion of this charge to the dealer as a reserve against losses or as a bonus. The controversy which has arisen as to these practices is discussed in Cavers, The Consumer's Stake in the Finance Company Code Controversy, supra, p. 200, at p. 204.

${ }^{8}$ For a discussion of these plans, see I Seligman, Economics of Instalment Seldino (1927) $75 \mathrm{et}$ seq.

'It is not to be supposed that the sales finance companies have entirely taken over the financing function. Some dealers do their own financing, especially in the case of used cars selling for \$r5o or less. In other cases where the finance company rejects the paper, or the buyer desires longer terms, smaller down payments, or lower finance charges, the dealer sometimes discounts at a bank. As Seligman points out, the experience of bankers with this type of paper varies, and there is a conflict of opinion among bankers themselves as to its soundness and advisability. 2 SELIGMAN, op. cit. supra note 8 , at 406 . Whether or not the car is used as security, the dealer generally assumes the burden of collecting for the bank. There is always the consideration that too much business may be disastrous to the dealer indorsing with recourse, when either the exhaustion of his credit line or a series of defaults leaves him without available funds for continuing his business. See Lorenz \& Motr-Smith, Financial, Pronlems of Instarament Selling (I93r) c. r. 
cleaners, etc. ${ }^{10}$. The reason for the difference in indorsements may be readily explained. The dealer is more willing to indorse with recourse on appliance sales, since depreciation is relatively small and the danger of loss through removal or default about half the ratio for automobiles. ${ }^{11}$ The finance companies' insistence is due to the burden of invading the housewife's kitchen and providing apparatus for removing and transporting the machine, a practical problem for which dealers are much better equipped than the finance company. In contrast the automobile is its own mode of transport and can usually be repossessed on the streets.

\section{The Non-Recourse Plan}

The dealer indorses the note without recourse. This method, first adopted by smaller finance companies to attract business from the larger ones, and as used more recently by the larger companies, is based in the main on the established business standing of the purchaser and dealer. The general policy is to reject all paper which is not an A-r risk ${ }^{12}$ unless the dealer sees fit to enter a more complete guaranty agreement which is acceptable to the finance company. ${ }^{13}$ In the usual case, the dealer's responsibility has ended with the purchase of the paper by the finance company, but there are occasionally situations when he will still have to make good the balance on warranties of the note or contract. Under his "recommendation, assignment and guaranty" which he has signed as part of the contract, the dealer usually agrees to be liable if title to the car is encumbered at the time of sale of the paper to the finance company, if the property is not as represented in the contract, or if he knew that statements made in the purchaser's statement were untrue. Further warranties in some of the contracts are to the effect that "the cash payment has been received and/or the trade in allowance is correct," and that all parties have capacity to contract. ${ }^{14}$

\section{The Repurchase Plan ${ }^{15}$}

The dealer indorses without recourse with a contract covering all transactions in

${ }^{10}$ A negligible, number of repurchase agreements exist even in this financing. The dealer is usually prevailed upon to repossess.

11 In new car sales for 1932, it was estimated that the ratio of defaults to the entire number sold on instalments was 4.5 per cent, while for domestic appliances it was 2 per cent. The Anticipated Dollar (Jan. 1933) 7 FORTUNE 68.

12 On the basis of the credit investigation (see note 5, supra), the purchaser is classified in one of three credit categories, e. g., "Very Good," "Fair," and "Poor," designated by letter or numerical symbol.

${ }^{28}$ Unlike the practice in the sale of paper subject to repurchase, the finance company alone inyestigates the purchaser in the non-recourse transaction. However, if the dealer evidences symptoms of becoming a mere order-taker, without regard to the purchaser's ability to pay the price, finance companies will avoid transactions to which he has been a party, or subject his paper to an even more rigid scrutiny.

${ }^{26}$ Practically the same warranties attach to the dealer's non-recourse indorsement of the note. NEGoTHABLE INSTRUMENTS LAW, $\$ 65$. The guaranty is absolute so that, even if the purchaser misrepresents his capacity to contract, the dealer is liable. Comm. Credit Co. v. Ward Auto Co., 215 Ala. 34, rog So. 574 (1926). Instead of a suit for breach of warranty there may be rescission and an action for the consideration paid the dealer. Comm. Credit Co. v. Third \& Lafayette Sts. Garage, 226 App. Div. 235, 234 N. Y. Supp. 463 (I929).

${ }_{1 s}$ Although usually the details of repurchase agreements are kept as private information, occasionally their importance in determining the legal rights of the dealer and finance company necessitates full disclosure in litigation. See Comm. Credit Co. v. Insular Motor Co., 17 F. (2d) 897 (C. C. A. Ist, 1927); C. I. T. Corp. v. Anderson, 165 Wash. 603, 5 P. (2d) 990 (193I). 
which he agrees to repurchase repossessed cars, ${ }^{16}$ or he indorses with recourse with an agreement ${ }^{17}$ providing that his endorsement shall not be enforced unless the car is returned. These so-called repurchase agreements constitute the means devised by the larger companies to meet the objections raised by dealers to the severity of the recourse plan. Most of their business is now conducted under such agreements, and although for reasons of competition they are obliged to handle non-recourse paper on occasion, they strongly discourage the use of the plan.

The repurchase plan provides protection against conversion or confiscation risks, since the dealer's liability arises only if the car is returned within ninety days after default. Since wreckage loss may be equally great, collision coverage is also provided. The protection accorded by this plan is for the benefit of the dealer only. ${ }^{18}$ The collision provision usually allows a deduction for the amount of repairs necessary or provides for repair by the finance company. It wrould seem that the larger finance companies usually act as their own insurers in furnishing protection against these risks to the dealer.

As a practical matter, regardless of the plan employed, the dealer and finance company are rarely found in opposition to each other in the courts. Mutual dependence and explicitness of their agreements is the probable explanation.

The contract and note having been sold to the finance company, consideration must now be turned to the position of the finance company as successor ${ }^{10}$ to the dealer's rights against that temporarily forgotten man, the purchaser. This requires an examination of the instruments employed to create and secure his obligation.

\section{The Credit Instruments}

\section{A. The Promissory Note}

As has been seen, the purchaser's contract is divided into two parts, the contract of sale and the promissory note. These instruments are kept distinct because the introduction of the terms of the contract into the note would jeopardize its compliance with the requirements as to the form of negotiable instruments, contained in the Uniform Negotiable Instrument Law, ${ }^{20}$ in force in every state. The note contains

\footnotetext{
${ }^{20}$ For the usual form of this type of repurchase agreement, see cases cited supra note I5.

${ }^{17}$ For the usual form of this type of repurchase agreement, see Gen. Motors Acc. Corp. v. Calhoun Chevrolet Co., 14 La. App. 258, 129 So. I68 (1930).

${ }^{18}$ At least one company's agreement with the dealer provides that no allowance will be made for collision damage if the dealer reveals to the purchaser that he (the dealer) is protected against such damage. See Universal Credit Co. v. Big Sandy Auto Co., 250 Ky. 557, 558, 63 S. W. (2d) 607, 608 (1933). The requirement by some of the large companies, since January 1 , 1935, of collision insurance for the purchaser, will thus protect the dealer more effectively.

${ }^{10}$ Western States Securities Co. v. Mosher, 28 Ariz. 420, 237 Pac. 192 (1925); Gen. Motors Acc. Corp. v. Smith, ror N. J. L. 154, 127 Atl. 179 (1925) (assignment of the secured debt does not require compliance with formalities of motor vehicle transfer law); cf. Merchants, ctc, Corp. v. Lane, 106 N. J. L. 576, 150 Atl. 559 (1930).

20 The decisions are in conflict on the question of how far a note may include the provisions of a security contract without impairing negotiability. Sec Brannan, Necottable Instruments Law (5th ed., r932) 127-130. The notes usually contain no reference to the contract although generally this would not impair negotiability. Ibid. Negotiability is not, however, affected by the customary attachment of
} 
a promise to pay to the order of the seller the unpaid balance of the purchase price and the financing charges, lumped in a single sum, ${ }^{21}$ payable in a specified number of equal instalments. The typical note includes virtually all the auxiliary provisions in aid of enforcement which the Negotiable Instruments Law regards as not impairing negotiability. ${ }^{22}$

\section{Provisions in Aid of Enforcement}

The principal ${ }^{23}$ provisions devised to this end would appear to be those for acceleration of the maturity of instalments not yet due, confession of judgment, collection of a 15 per cent attorney's fee, and waiver of exemption and homestead rights. ${ }^{24}$

"Upon non payment of any instalment the whole sum immediately becomes due and payable." It is usually held optional with the holder to enforce this acceleration clause, whether or not the note provides for the option. ${ }^{25}$ It is well to note that the usual step where there is default accelerating payments is to repossess the car, rather than to sue on the note. The contract as well as the note usually contains provision for acceleration in the event of default, a provision of especial utility where the purchaser is in default in some respect other than non-payment of instalments, as, for example, unauthorized sale of the car. If this default took place a few days after an instalment payment had been met, no action could be brought on the note till an instalment was due, since the note only provides for acceleration upon non-payment of an instalment.

The drastic nature of proceedings under warrant of attorney to confess judgment, which eliminates notice and any opportunity to present a defense, has led to statutes ${ }^{26}$ or decisions ${ }^{27}$ in many states prohibiting such confessions. Statutes requiring the filing of an affidavit signed by the defendant, acknowledging the indebtedness and setting forth the transaction out of which it arose, seem to have effectually served

the note to the contract by perforations. Comm. Credit Co. v. Smith, I 43 Misc. 478,256 N. Y. Supp. 759 (1932). Nor is subsequent detachment a material alteration avoiding the note. Conqueror Trust Co. v. Simmon, 62 Okla. 252, I62 Pac. I098 (r917). Contra: Gen. Motors Acc. Corp. v. Garrard, 4 I Idaho 151,238 Pac. 524 (1925).

${ }^{21}$ The inclusion of the finance charge in the credie price is held to remove the transaction from the operation of the usury laws. For a criticism of this doctrine, see Berger, Usury in Instalment Sales, supra, p. $\mathrm{I}_{4} 8$.

${ }^{22}$ Sec Negotiable Instrument Law, $\$ \$ 4(2), 5(2), 2 \cdot(5), 5$ (3).

${ }^{2 s}$ Other provisions of less significance include waivers or prohibitions of the exercise of the right of change in venue or of appeal. These are generally held to be contrary to public policy. Gen. Motors Acc. Corp. v. Talbott, 38 Idaho 13, 219 Pac. 1058 (r923); Gen. Motors Acc. Corp. v. Codigo, 62 Cal. App. II7, 216 Pac. 383 (1923).

${ }^{21}$ The state decisions conflict as to allowing waivers of exemption. Public policy is invoked as the usual ground for not permitting it. (I930) 44 HArv. L. REv. 463. In some states the exemption statute expressly permits waiver. Ibid.

${ }_{25}$ Putthoff v. Walker, 213 Mo. App. 228, 248 S. W. 6rg (I923).

*E.g., Ala. Code (Michie, I928) \$8047; Fla. Gen. Laws (Skillman, I927) \$4495; Ky. Stat. (Carroll, 1930) \$416; Miss. ANs. CoDE (Hemingway, 1930) \$60r.

Ir The cases so holding generally go on the ground of public policy. Hamilton v. Schoenberger, 47 Iowa 385 (1877); First Nat. Bank v. White, 220 Mo. 717, 120 S. W. 36 (I909). 
the same purpose. ${ }^{28}$ In Indiana and New Mexico procuring the execution of or attempting to enforce a judgment note is a misdemeanor. ${ }^{29}$ Even in the minority of jurisdictions ${ }^{30}$ which do permit such judgment notes, very definite limitations ${ }^{31}$ have been placed on their use. Judgments obtained by confession in states where this procedure is permitted are not always recognized when sued on in states holding the contrary view. ${ }^{32}$

Most states have been more liberal in recognizing stipulations in notes of attorney's fees. ${ }^{33}$ Only a few states have outlawed such provisions. ${ }^{34}$ The fee is authorized if the note is paid after confession of judgment ${ }^{35}$ or after having been placed in the hands of an attorney for collection. ${ }^{36}$ The notes usually provide for attorney fees of 15 per cent of the unpaid balance, although one note, used by a large company, provides for a fee of 15 per cent of the entire principal amount of the note. ${ }^{37}$ Ordinarily the fee will be allowed unless the defendant purchaser sustains the burden of showing that it is excessive, ${ }^{88}$ in which case whatever the jury determines to be a reasonable fee will be allowed. ${ }^{39}$

\section{The Significance of Negotiability}

Aside from the need of absolute negotiability for assuring easy rediscounting, ${ }^{10}$

${ }^{23}$ See McCrairy v. Ware, 6 Kans. App. 155, 158, 5I Pac. 293, 294 (1897); First Nat. Bank v. White, supra note 27, at 738, 120 S. W. at 42; U. S. Fid. Co. v. Shickler, 199 App. Div. 74, 191 N. Y. Supp. 194 (I92I). payce).

${ }^{29}$ IND. Stat. (Baldwin, 1934) \$398; N. M. Laws 1933, c. 48 (adding also possession as indorsee or

${ }^{30}$ E.g., Del. Rev. Code (1915) No. 4199; Ili. Rev. Stat. (Smith-Hurd, 1933) c. Iro, \$88; PA. Stat. ANN. (Purdon, 1930) tit. 12, No. 316.

31 The sum must be liquidated or susceptible of liquidation without reference to matters extrinsic to the note, C. I. T. Corp. v. Powell, $x 66$ Md. 208, 170 Atl. 740 (1934), and the authority given must be strictly pursued. Grover Sewing Machine Co. v. Radcliffe, 137 U. S. 287 (1890). Usually the judgment may be reopened or vacated upon filing an affidavit of meritorious defense. Comm. Cred. Co. v. Calkins, 78 Colo. 257, 24 I Pac. 529 (1925); Auto Brokerage Co. v. Meyer, I54 Md. I, I39 Atl. 539 (1927).

22 The note usually provides for confessing 'judgment in any court of record in the United States. Whether a judgment so obtained is entitled to full faith and credit under the United States Constitution when the note -was made or was payable in a state prohibiting such confessions is a doubtful question. See Note (1930) 44 Harv. L. Rev. r275; (1935) 3 Duke B. Ass'n J. 32.

As to such a stipulation, one court observed, "Saving the debtor from oppression should not mean relieving him from the force of his own contract and the effects of his own default by absolving him from his contractual liability, and transferring the burden he assumed to the one for whose benefit he engaged to assume it, unless at least the obligation is on its face unjust and oppressive." Comm. Inv. Trust, Inc. v. Eskew, 126 Misc. 114, 116, 212 N. Y. Supp. 718, 721 (1925).

"H.g., N. C. Code (Michie, I931) \$2983; N. D. Comp. Laws (1913) 57791. Cf. Neb. Comp. Stat. (1929) \$62-102 (no sum not allowable in other cases).

${ }^{2}$ In re Harris, 272 Fed. 351 (M. D. Pa., 1921).

${ }^{28}$ Maxey v. Somerton State Bank, 22 Ariz. 371, 197 Pac. 894 (I92I).

"Such a basis for determination has been sustained by some courts. Am. Savings Bank v. Sutton, 204 S. W. 572 (Mo. App. rgr 8) (four-fifths had been paid); of. Dunn v. Vaughan, r20 Okla. 240, 251 Pac. 472 (1926) (no provision in note as to how to be determined).

"Osage Oil, etc. Co. v. Dickason-Goodman Lumber Co., I06 Okla. II9, 23I Pac. 475 (1924).

' Hillside State Bank v. Christensen, 32 Wyo. 68, 229 Pac. I05 (r924); McCreary v. Stevens, 156 Miss. 330, 126 So. 4 (1930). Contra: Phosphate Co. v. Jenkins, I20 S. C. 337, I13 S. E. 317 (1922) (for court, under power to control attorneys).

${ }^{\circ}$ On the practice as to rediscounting this paper, see Grimes, Financino Autosodile Sales (r926) 64 et seq. 
there are certain recurring types of situations in automobile financing where the finance company has found dealer abuses which necessitate cutting off defenses of the car purchaser. ${ }^{11}$ The type of defense which one might anticipate would be encountered most frequently, namely, that the car sold was defective, is precluded by a clause in the contract to the effect that "said car is accepted without any express or implied warranties unless written hereon at date of purchase." 12 Such a provision, however, would not protect the dealer in case he made fraudulent misrepresentations to the purchaser. ${ }^{48}$ Two other situations in which the finance company finds the note of utility in cutting off defenses are the following:

(I) Trouble with purchasers who had made payment to dealers early led to inclusion in the contracts either provisions that payment to anyone other than the finance company does not constitute payment or more direct agreements not to deal with the seller as agent of the finance company for any purpose whatsoever. ${ }^{4}$ In practice, however, the purchaser for the sake of convenience or in response to demand by a fraudulent dealer, sometimes makes payments to the seller. As long as the payments are actually sent in, no trouble arises. However, the danger of dealer payments has led the finance company to keep a check on payments coming from dealers and investigate when such payments reach a certain percentage.

(2) An interesting situation arises where the finance company has been the innocent victim of a so-called "phony deal" which consists of a sale of the contract and note where no car has been sold.45 Though not nearly so prevalent as formerly,

a Since the contract as well as the note contains a promise to pay, an attempt which has been made to obtain the benefits of negotiability by 2 provision in some of the contracts precluding the purchaser from setting up "any claim against the seller as defense, counterclaim, set-off, cross complaine, or otherwise" is probably invalid. Am. Nat. Bank v. Sommerville, Igr Cal. 364 , 216 Pac. 376 (1923). A contrary view has been urged for the sake of business convenience or to effectuate the expressed intention of the parties. Note (1924) 33 YALE L. J. 302; Brannan, op. cit. supra note 20, at 91. It would seem that if the barring of defenses is desired, it should be effected by complying with the Negotiable Instruments Law. In addition, it may well be argued that the purchaser merely by signing the contract has expressed no real intention to waive such defenses, in view of the lengthy, closely printed contract which he has probably not read, and will not fully comprehend if he does read it. Public policy would seem to forbid such opportunities for deception. Motor Contract Co. v. Van der Volgen, I62 Wash. 449, 298 Pac. 705 (I93I).

$\checkmark$ When the sales contract contains an express warranty, there is a possibility that a court will construe the note and contract together and deny to the finance company the protection accorded a holder in due course. This was done in J. I. Case Co. v. Cox, 178 S. E. 585 (N. C. I935) (note referred to contract).

is But the finance company as holder in due course of the note will be protected. Auto Brokerage Co. v. Ullrich, I02 N. J. L. 34I, r34 Atl. 885 (r926). If the note is regarded as carrying with it the right to resort to the security, the defenses may be barred even in actions to recover the property under the contract. Comm. Credit Co. v. Summers, 154 Miss. 501, 122 So. 54 I (1929).

"The inclusion of such a provision is valuable to give notice and to evidence the general practice. Comm. Inv. Trust, Inc. v. Carrano, 104 Conn. 302, 132 Atl. 87o (1926); of. Gen. Motors Acc. Corp. v. Fletcher, 202 N. C. I70, I62 S. E. 234 (1932) (dealer held to be agent to receive payments in absence of such a provision). Direct payment to the company secures speed in collection, especially important in these transactions. Sce Grimss, op. cit. supra note 5, at 52.

w One of the contracts carries the following warning in large bold face type under the space provided for the purchaser's signature to the contract: "Purchaser. Read Before Signing: Purchaser sign here if car is actually in your possession, but do not sign here uniess you have actually received the car, since by doing so you might place yourself in the position of being a party to a fraud." 
clever but dishonest dealers continue occasionally to mulct the finance companies of large sums. In one scheme, the dealer paid respectable but ignorant people a dollar a month to turn over mail to him from his "mail order company" and induced them to sign sales contracts and notes unknowingly. In turn he sent in payments under their names in varied forms, completely deceiving the finance company. The usually effective precautions used by the finance company, such as, checking the percentage of dealer payments, discreetly-worded form requests to purchasers asking that payments be made direct to the company to avoid inconveniencing the dealer, and the "insurance subterfuge," ${ }^{\text {"6 }}$ availed nothing, and it was only many months later when the dealer had fallen behind in payments that his chicanery was discovered. In other instances forged. indorsements of responsible parties were used on contracts of fictitious buyers, the dealer opening accounts in these false names and then making payments. Often a financially irresponsible salesman of the dealer is used as the pseudo-buyer, with the dealer retaining the car and selling it to a third party. ${ }^{47}$ As against the dealer the finance company will usually be left to share with general creditors. Negotiability here becomes important in the instances where the maker of the instrument is financially able to pay. In such cases, negotiability serves to prevent interposition of a defense of lack of consideration. ${ }^{48}$

\section{B. The Security Contract}

Rigorous contractual provisions for payment are of little value where the debtor has defaulted and has no money, nor does a provision for retention of title mean much unless there is some way to prevent the property slipping through the fingers of the finance company. As a result, there are in the contract provisions to cover almost every act of the buyer which might lead to such loss. Finance companies operating nationally. prepare different contract forms for use in groups of states the relevant laws of which are substantially uniform. Nevertheless, variations of law even within such groups are such as usually render certain of the provisions unenforceable in some of the states for which the contract is designed. ${ }^{40}$ The legality of other provisions may remain open to question. The cautious draftsmen of these instruments resolve all such doubts in their own favor, ${ }^{50}$ but include in each contract

\footnotetext{
${ }^{10}$ This consists of a letter stating that there has been a mistake as to the buycr's insurance on his Ford $x-1234$ and requesting certain information. In reality the buyer is supposed to have Buick q-6789 If he does have the Buick his reply will indicate it, but a reply giving information on the Ford $\mathrm{x}-1234$ would bring immediate investigation. This plan fails where the inquiry is turned over to the dealer by his dupe or accomplice.

${ }^{a}$ The bona fide purchaser has been held to prevail as against the finance company, even where the fictitious contract is recorded. Comm. Credit Co. v. Hazel, 214 Iowa 213, 242 N. W. 47 (1932).

${ }^{2}$ Universal Credit Co. v. Thomas, 170 Miss. 21 , 154 So. 272 (1934); Gen. Motors Acc. Corp. v. Larson, 110 N. J. Eq. 305, I59 Atl. $8 \times 9$ (1932); Motor Finance Corp. v. Huntsberger, 116 Ohio St. 317, I56 N. E. III (1927).

${ }^{\text {so }}$ For example, the provisions for confessing judgment and collecting attorney fees included in one contract for use in the states of Iowa, Kansas, Nebraska, New Jersey, New York, Oklahoma, South Dakota and Wyoming, are obviously not enforceable in all of these states. See notes 27, 28, 34, supra.

${ }^{\infty}$ Thus the contract of one company for Kentucky still provides for resale without notice, although such a provision was held invalid more than two years ago. Gen. Motors Acc. Corp. v. Dickinson, 249 Ky.
} 
a "separability clause" of which the following is typical: "Any part of this contract contrary to the law of any State shall not invalidate other parts of this contract in that State." There is, however, little reason to believe that the inclusion of these outlaw provisions is utilized to gain unfair advantages as may often be the case in some branches of the instalment credit business where amounts involved are smaller and the resort to legal advice less frequent.

As might be expected in such a document drawn purely for protection of the seller and his assignee, the purchaser is left with few, if any, contractual privileges. Statutory enactments of solicitous legislatures, ${ }^{51}$ coupled with skilful bits of judicial prestidigitation $^{52}$ and the ever-amazing antics of juries ${ }^{53}$ have served to curtail to some extent these seemingly secure provisions with results not always fair to the finance companies. Necessity for preserving consumer good-will leads the better finance companies to limit resort to the harsher provisions of the contracts to cases involving fraudulent or obdurate debtors. This fact, together with the reluctance of purchasers to carry cases involving relatively small amounts. to the higher courts, leads to a dearth of appellate opinions on many of the points involved. ${ }^{54} \mathrm{Un}$ doubtedly, however, stringent provisions, even though not generally exercised, have a salutary deterrent effect on irresponsible purchasers.

\section{The Form of the Security Device}

Collateral security for the personal promise of the purchaser and indorser is usually afforded through the legal device of retention of title to the car sold. This security title passes to the finance company upon the assignment of the sale contract. ${ }^{\text {55 }}$ 'Title is normally retained through the use of a conditional sale, which is nothing more than a delivery of possession to the buyer subject to the condition that the title to the property shall not vest in the buyer, until payment of the purchase price. ${ }^{68}$

422, $60 \mathrm{~S}$. W. (2d) 967 ( 1933 ). The retention of the provision is perhaps justifiable on the theory that the court was influenced in that case by the inequitable nature of the sale, two-thirds of the price having been paid, and may not be so exacting where a much smaller amount has been paid by the purchaser at the time of default.

"Although the contracts do not provide for redemption of the property by the buyer after it has been retaken by the seller, the concession has been achieved by the enactment of statutes whose requirements cannot be waived. 3 Jones, Chatfel Mortgages and Conditional Sales (6th ed. 1933) \$997.

tIllustrations of such dexterity are to be found most frequently in the application of the doctrine of election of remedies and in distinguishing between the various forms of security devices, problems which are discussed below. See pp. 237-239, infra.

0 The jury's ability to conveniently overlook testimony is illustrated by Gen. Motors Acc. Corp. v. Sanders, 184 Ark. 957,43 S. W. (2d) 1087 (r93I). Here, despite admitted default and the delinquent buyer's failure to tender the entire sum due, the jury found that he was not in default, a finding which the appellate court felt constrained to accept. See Wilson, Recent Developments in the Law of Conditional Sales (I932) 66 U. S. L. Rev. 421 at 430.

"An examination of a large number of reported cases to which finance companies were parties revealed that in the great majority of such cases the finance companies were the appellants.

See note 19, supra.

${ }^{8}$ UNI. Cond. SALES ACT, \$1; see Vold, The Divided Property Interests in Conditional Sales (1930) 78 U. of PA. L. REv. 713, for an excellent analysis of the nature of the device. 
Another device employed for retaining title, chiefly in Pennsylvania, ${ }^{57}$ is the bailment lease under which the lessee hires the use of the property, agreeing to pay rent in amount and for a period of time similar to that provided in an instalment sale contract, with the option at the completion of the rental period to obtain title to the car upon the payment of a nominal sum. ${ }^{58}$ In adopting the Uniform Conditional Sales Act ${ }^{59}$ which treats the bailment lease as a conditional sale, ${ }^{60}$ Pennsylvania omitted this provision. Since a bailment lease need not be recorded in Pennsylvania, this exception in the Act has created there the strange anomaly of upholding a device originally devised as a subterfuge to evade Pennsylvania decisions invalidating conditional sales as fraudulent conveyances, after the conditional sale, safeguarded by provisions for recordation, had been accorded statutory recognition. ${ }^{01}$ The result has been that the bailment lease is still resorted to in lieu of the conditional sale.

Alternative to the conditional sale and bailment lease is the chattel mortgage, executed by the purchaser to the dealer upon sale of the car, securing payment of the unpaid balance of the credit price. ${ }^{62}$ Less stringent recording requirements, ${ }^{63}$ possible economies in recording fees, as well as more expeditious remedies in the event of default, have led to concentration on the conditional sales form wherever it is allowed. In Texas, however, the conditional sale is declared to be a chattel mortgage by statute, ${ }^{64}$ and in a few states, Colorado, Louisiana, Missouri, Ohio, Michigan, and Washington, judicial decisions, ${ }^{65}$ based either on public policy or indistinguishability of the devices, have necessitated use of the chattel mortgage. The theoretical difference between the conditional sale and chattel mortgage transactions is merely formal, the conditional sale in reality being a short cut to an absolute sale with mortgage back. ${ }^{86}$ However, courts and legislators in most states have classified them separately, ${ }^{87}$ provided for their separate recordation, and, as will be seen, have

${ }^{6}$ Aside from Pennsylvania there is apparently little use of the bailment lease in this country. However, in England a device similar in nature, "the hire-purchase agreement," is widely used for instalment selling. See Midland Motor Showroom, Ltd. v. Newman [1929] 2 K. B. 256; Gough v. Wood \& Co. [r894]. I Q. B. 7r3.

${ }^{85}$ Gen. Motors Acc. Corp. v. Hartman, 174 Atl. 796 (Pa. 1934). See Montgomery, The Pennsyluania Bailment Lease (I93I) 79 U. of PA. L. REv. 920.

EP Pa. Laws 1925, No. 325, PA. StAT. (Cum. Supp. 1928) \$19727 a-1 et seg. Eight states and the territory of Alaska have adopted the act. The states are: Arizona, Delaware, New Jersey, New York, Pennsylvania, South Dakota, West Virginia, Wisconsin.

${ }^{\infty}$ UnI. Cond. Sales Act, \$I.

" Montgomery, supra note 58 , at 938 . 1 Jones, op. cit. supra note $5 \mathrm{r}, \$ \mathrm{x}$.

* All states have some recording requirement applicable to chattel mortgages, but only 35 require registration of conditional sales. Hanna, The Extension of Public Recordation (193I) 31 CoL. L. Rzv. $617,638$.

a Tex. Stat. (Vernon, 1928) art. 5489.

The decisions are collected in 3 Jones, op. cit. supra note $51, \$ \$ 937,938$.

os "The chattel mortgage involves three steps-a delivery of possession, a transfer of title to the buyer, and a transfer of title back to the seller for security; while a conditional sale involves one step only-a delivery of possession to the buyer, leaving the title in the seller for security. The result accomplished is absolutely the same." Bogert, The Evolution of Conditional Sales Law in New York (1923) 8 CorN. L. Q. 303, 304.

"See Quinn v. Bancroft-Jones Corp., 18 F. (2d) 727 (C. C. A. 2d, 1927), where the court said: "While" it may be true that mortgages and conditional sales are only formally different, the difference has 
permitted important rights of both parties to depend on the category into which a given transaction could be forced. Needless to say, this effort to distinguish Tweedledum from Tweedledee has been prolific in litigation.

Regardless of the form of security device employed, the company's security interest is fortified by conditions ${ }^{88}$ which restrict the buyer's privileges of use, sale, and encumbrance of the car or which enable the company to declare the buyer in default in the event that his credit-standing becomes impaired.

2. Limitations on Use, Sale, and Encumbrance

A typical clause limiting the use, sale, and encumbrance of the property is set forth below. Upon breach of any condition therein there may be repossession, resale, and suit for deficiency under the contract ${ }^{68}$ or an action in tort for conversion: ${ }^{70}$

"Said car shall not be used for taxicab purposes or for hire unless otherwise mentioned herein. Purchaser shall not remove or attempt to remove said car from the county and state given above as Purchaser's address without the written consent of the seller. Purchaser shall not sell, lend, mortgage, assign, encumber, secrete, lose possession or dispose of said car or this contract or any interest therein. Purchaser shall pay all taxes and fees of every nature in connection with said car. Purchaser shall not suffer or permit any lien, encumbrance or charge against or upon said car. Purchaser shall not use or permit said car to be used contrary to any laws in respect to intoxicating liquors, narcotics or other products and shall conform with all laws governing said car."

Provisions against use for hire are reputedly seldom resorted to nor are the ones against illegal use. Normally, as long as payments come in regularly, the finance company will have no cause to investigate. When default in payment has occurred the resort to the hire provision in order to repossess will not be necessary. Apparently this provision is included chiefly to deter attempts to avoid the higher financing charges for cars to be used as taxicabs. Exercise of default remedies against the purchaser in the case of illegal use seldom, if ever, occur. The company will usually obtain notice of such a breach through the seizure of the car and institution of forfeiture proceedings by state or federal authorities. Under most state prohibition laws and the late National Prohibition Act, the finance company was permitted to recover the car upon a showing that it had no knowledge or reason to know that the buyer

long been part of the common law, has been recognized in legislation, and cannot be disregarded by the courts." Thus, although the theory of the Uniform Conditional Sales Act is that the two should be treated alike, the existence of separate statutes and decisions recognizing distinctions of various sorts necessitates keeping the two transactions distinct and the use of different names for each. Bogert, Commentaries on Condittonal SALES, $2 a$ U. L. A. (1924) ri.

- Actually, these restrictions on the buyer are phrased in the form of promises, being prefaced by "the purchaser agrees," "the purchaser promises." However, it is difficult to conceive of any situation in which the company would sue for breach of one of these promises rather than for the car or its value in tort or for the unpaid balance due under the contract. Since in reality these "promises" are intended as conditions upon which possession and right to attain ownership depend, they should be construed as conditions. See 2 Wiliston, Contracts (r920) $\$ 673$.

The use of these remedies is discussed on pp. 235-240, infra.

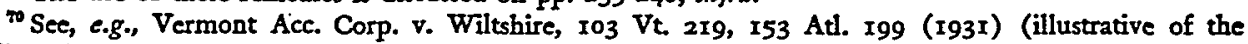
utility of such a remedy when buyer could bave defended in a suit under the contract or note because of infancy). 
was using the car illegally. ${ }^{71}$ Today, despite the repeal of the Volstead Act, the car may still be confiscated under the federal internal revenue or customs laws. ${ }^{72}$ Under these acts, the finance company can rarely recover the car ${ }^{73}$ and is left to pursue its remedies against a will-o-wisp purchaser, whose discovery is also being sought for the purposes of criminal action. Losses from this source are few in number, however, because a thorough credit investigation usually reveals with accuracy the buyer's source of income and his occupation, unless he is leading a Jekyll-and-Hyde existence.

The narrowing of state boundaries through improved highways and faster cars would create a tremendous burden on the finance company and buyer if the provisions as to removal were literally enforced. Because of this practical burden and the fact that courts usually do not consider the removal a default unless permanent, ${ }^{74}$ the enforcement of default for temporary removal is practically unknown. On the other hand, where the removal is permanent, the purchaser usually complies with the contract by securing written permission to remove the car. Far-flung branch offices of the national companies ${ }^{75}$ coupled with the usual standing of the purchaser as a good credit risk facilitate the handling of permanent removal cases. However, "skip" cases, i.e., cases of removal of the car with intent to conceal or defraud, are occasionally encountered. Over a period of years the number of "skip" cases has averaged approximately 5 in $1000 .^{78}$ One credit executive has stated that approximately 80 per cent of these cars are recovered. In relatively few instances there have been prosecutions under statutes prohibiting removal with intent to defraud, ${ }^{77}$ a

$n_{3}$ JoNes, op. cit. supra note 5I, \$1424 (state rules); Black, Some Prohibition Forfeiture Cases-the Doctrine of Vicarious Liability (1930) $78 \mathrm{U}$. of PA. L. REv. 518; McDonald, Automobile Forfeitures and the Eighteenth Amendment (I93I) Io TEx. L. REv. I4I; Note (1925) II VA. L. Rev. 628.

${ }^{72}$ Internal Revenue Act, I4 STAT. I5I (1878); 26 U. S. C. A. 51182, or the Tariff Act, 14 STAT, 178 (1878); I9 U. S. C. A. $\$ 483$. When prosecutions were brought under the Prohibition Act, confiscation proceedings had to be brought under its provisions rather than under the revenue or customs laws. Comm. Credit Co. v. U. S., 276 U. S. 226 (I928).

$7 \mathrm{~A}$ few exceptions are recognized. If the car has been stolen, forfeiture is avoided. U. S. v. One Ford Coupe, 2I F. (2d) 639 (S. D. Idaho, I927). Most significant, however, is the provision which has been included in the Tariff and Internal Revenue Acts for some seven years, permitting remission or mitigation of forfeitures incurred without wilful negligence or intention on the part of the owner or lien holder to violate the law. 46 STAT. 757 (1930), 19 U. S. C. A. 516r8; 45 STAT. 882 (1928), 26 U. S. C. A. \$2709. The procedure is by a petition to the proper cabinet official-the Secretaries of Commerce and the Treasury, the Attorney General. The determination of the rights of the petitioner is not reviewable in any court. General Fin. Co. v. U. S., 45 F. (2d) 380 (C. C. A. 5 th, r930). The standard of care imposed is exceedingly strict, and in practice the result has been that the car is seldom recovered. See McDonald, supra note 71 , at 145 . One petition seen by the writer had been refused even though it set forth that investigation had revealed the tax evader to be a real estate agent of 15 years standing, an eminent citizen of his community, and never known to have been involved in liquor law violations.

"Nat. Bond \& Inv. Co. v. Dickens, 230 Pac. 911 (Okla. 1924); Street v. Comm. Credit Co. 35 Ariz. 479, 281 Pac. 46 (1929); cf. UNr. Cond. Sales Acr, \$r3.

In the case of local companies, the coojperation of the finance company operating in the territory to which the car is removed is often secured, usually through the good offices of finance company trade associations.

This figure is based on reports of the National Association of Sales Finance Companies.

${ }^{3} 3$ JONEs, op. cit. supra note 51, 51426. 
remedy which is seldom successful because of the difficulty of proving the necessary intent.

Provisions against sale and encumbrance present an interesting variation from the usual practice with respect to real property where sale or encumbrance of mortgaged land is a commonplace. Since the relationship of finance company and purchaser is purely an impersonal one, the practice has become general to waive the condition ${ }^{78}$ in the case of sale to a third person, provided he is as good a credit risk as his predecessor. Under Section I3 of the Uniform Conditional Sales Act, provisions against the conditional purchaser selling, mortgaging or otherwise disposing of the property are recognized as valid. ${ }^{79}$. In some 27 states unauthorized sale by the buyer is made criminal by statutes of two types. ${ }^{80}$ In one type, the mere act of selling without first obtaining written consent is sufficient to constitute the offense, while in the other there must be a fraudulent intent. In some jurisdictions, however, the conditional buyer may transfer or encumber his interest even though there are special restrictions in the contract to the contrary, the transferees being entitled to retain the goods upon payment or tender of full performance. ${ }^{81}$

The related problem of defaults occurring through the accrual of liens of various sorts concerns almost wholly the finance company and the lien claimants. In practice the debtor behind in taxes, owing a large garage bill, or selling the car either fraudulently or of necessity is unlikely to furnish much satisfaction in the event of a judgment. License and personal property taxes are usually the only taxes which are imposed on the conditional purchaser by reason of his interest in the car. Without paying the former he cannot operate the car, and a delinquency in the latter will give the political unit no lien as against the finance company. ${ }^{82}$

\section{Insecurity and Insurance Provisions}

In addition to the specific conditions in the contract restricting use and disposal of the automobile by the purchaser, there are also provisions which may be exercised when the credit standing of the purchaser has become impaired. These may be grouped under the general heading of "insecurity" provisions.

Some of the contracts do no more than state that if "the holder [of the contract] shall deem itself insecure" its contractual remedies may be exercised. This clause

\footnotetext{
Tome of the contracts do not contain any provision for obtaining written consent of the finance company, but instead absolutely prohibit sale.

To However, in the absence of contractual provision, this section permits sale or encumbrance if notice is given in writing ten days prior to the transfer.

'Commissioners' Note to Uni. Cond. Sales Act, \$r3, 2 U. I. A., (r922) 23.

Clinton v. Ross, 108 Ark. 442, 159 S. W. II03 (rgr2); Davies-Overland Co. v. Blenkiron, 7r Cal. App. 690, 236 Pac. 179 (1925).

Een. Motors Acc. Corp. v. Whitfield, 253 N. W. 450 (S. D. 1934); Pac. Finance Corp. v. Snohomish County, II3 C2l. 773, 295 Pac. 8 ro (193r). The clause that the purchaser shall keep the property free of all taxes, etc., was deemed "worthy of consideration" in determining that the finance company was entitled to repossess, despite the fact that the purchaser owed taxes for use of the highways which were by statute a first lien. Universal Credit Co. v. Mamminga, 214 Iowa Ir35, 243 N. W. 5I3 (I932). Contra: Motor Dealer's Credit Corp v. Heise, I66 S. C. 389, 164 S. E. 900 (1932). The problem of garage liens will be considered later.
} 
has been sustained as valid, ${ }^{83}$ but the courts require that the seller show reasonable cause for insecurity. ${ }^{84}$ The application of this criterion of justification will depend on the facts of the particular case. ${ }^{85}$ Other contracts, more expansive in terms, give the finance company the right to declare a default:

"If any execution, attachment or other writ should be levied on any of Purchaser's property, or if a petition under the Bankruptcy Act or any amendment thereof should be filed by or against Purchaser or a receiver of the property of the Purchaser should be appointed, or if for any other reason Seller should deem itself or said car insecure, Seller or his representative may take possession. ..."

Where the company's security interest is senior to that of the attaching creditor, trustee in bankruptcy, or receiver, the value of this power to repossess is evident. Conversely, it is of no value where the company's interest is junior to that of the purchaser's creditors. The problem of priorities will be discussed in a later section.

To protect the property against damage or destruction, the contracts either provide that "Seller may insure said property against fire and theft to properly protect Purchaser and Seller and Purchaser shall pay the premium" or "Purchaser shall keep said car insured against fire and theft payable to and protecting Seller, for not less than the total amount owing on said note until fully paid, and Seller may place said insurance at Purchaser's expense, if Seller so elects." Coupled with the insecurity provisions' noted above, there is usually a provision that cancellation of this insurance by the insurance company places the purchaser in default under the conditional sale contract.

Formerly, the contracts provided that the purchaser would procure insurance satisfactory to the seller. The result was frequent loss because of insuring-in small, Aly-by-night companies. Today the practice is universal to include insurance premiums in the financing charges, the account being turned over to a broker to place. As previously noted, ${ }^{86}$ the trend is now towards requiring collision insurance-which has always been urged-as well as the standard fire and theft coverage. Apparently the proceeds would be used to discharge the balance due, but some contracts provide that the money may be used toward replacement of the property or payment of the obligations, at the option of the seller.

A problem of risk of loss arises when there is damage not covered by insurance, such as collision. In but one of the contracts examined by the writer is there an express provision that the property shall at all times be at the purchaser's risk. This provision is declaratory to the very general rule that the risk of loss in conditional sales is on the buyer. ${ }^{87}$ Where the car is injured by the negligence of a third party, the finance company may sue for the damage done, ${ }^{88}$ its recovery being limited to

ESTRICH, INSTALMENT SALES (1926) \$360.

st 1bid., citing Hines v. Pacific Car Co., 110 Wash. 75, I88 Pac. 29 (1920).

${ }^{85} 3$ JoNes, op. cit. stipra note 5I, \$1296.

' ${ }^{2} U_{N I}$, SALES ACT, \$22 (a); UNI. CoND. SALES ACT, \$27. As to the weight of authority at common law, see I Williston, SAzEs (2d ed. 1924) $\$ 304$.

Barnes v. United Ry., I 40 Md. I4, I 16 Atl. 855 (1922); see Carolina, C. \& O. Ry. v. Unaka Springs Lumber Co., 130 Tenn. 354, 381, 170 S. W. 591, 598 (1914). 
the balance due. ${ }^{89}$ Contributory negligence of the purchaser is no defense in such an action, ${ }^{90}$ but a previous settlement by him does bar a subsequent suit by the finance company. ${ }^{91}$ In the case of settlements, it is generally said that the conditional buyer must account to the seller or his assignee to the extent of his interest. ${ }^{92}$ Actually the experience of finance companies has often been that a judgment-proof purchaser, having been involved in a wreck, will sign a release for a consideration. Rather than leave the finance company with a piece of worthless junk it would not seem too harsh, at least in certificate of title states, to require the tortfeasor to make a reasonable attempt to ascertain whether or not the injured party has title to the car.

\section{The Delinquent Purchaser}

Regardless of the purchaser's success in observing or evading the foregoing conditions imposed by the contract, let him once fail to obey the commandment, "Thou shalt pay," and immediate action on the part of the finance company is sure to be forthcoming. However, everything possible is done to facilitate payment. Immediately upon its purchase of the debt, the company sends notice ${ }^{83}$ to the car purchaser by form letter. The form letter states that Ardue Finance Company has purchased his conditional sale contract and note, that payments are to be sent to the office designated on the outside cover of the enclosed handy little coupon book, containing a coupon with number, amount and date of each payment, one to be sent with each remittance "for certainty of our records." In addition, advance notice is given of the pendency of each instalment.

Generally the defaulter shows up within the first three months after purchase. ${ }^{\text {a }}$ Once past the first few payments, the purchaser will move heaven and earth to protect his "equity." There is normal expectancy that 980 out of every thousand will complete the transaction; even in present times, the expectancy is $95^{\circ}$ per thousand. ${ }^{95}$

${ }^{80}$ The authorities are not at all clear on this point, but the above statement seems to be the majority rule. Lacey v. Great Northern Ry., 70 Mont. 346, 225 Pac. 808 (1924); I Williston, Sales, \$333; Estrich, op. cit. supra note $83, \$ \$ 220,221$. Since it is usually held that the purchaser may recover the full value, holding the company's interest in trust, it would seem on principle that the converse of the rule should be applied here to prevent multiplicity of actions.

${ }^{50}$ Comm. Credit Co. v. Satterthwaite, I07 N. J. L. I7, I50 Atl. 235 (1930); Note (1930) 40 Y ALI L. J. 135 .

${ }^{92}$ Ellis Motor Co. v. Hancock, 38 Ga. App. 788, 445 S. E. 518 (1928); Harris v. Seaboard Airline Ry., I90 N. C. 480 , 130 S. E. 3 19 (1925).

${ }^{12}$ Carolina, C. \& O. Ry. v. Unaka Springs Lumber Co., supra note 88.

${ }^{2}$ A failure to send notice is important in case the note is declared non-negotiable. In such a case, failure to give notice would permit the defense of payment or a binding change in the contractual terms. Stella v. Bankers Comm. Corp., I97 App. Div. 515, I89 N. Y. Supp. 5 II (1921); Hare \& Chase v. Volansky, 127 Misc. 26; 215 N. Y. Supp. 168 (1926).

ot The incidence of default is claborately examined in 2 Seligman, op. cit. supra note 8, at 405-506. The writer has been informed by credit executives of leading finance companies that early default is encountered most frequently in the winter season when cars are a source of more trouble and less enjoyment and when increased personal needs diminish the buyer's cash resources. The repossession study in Seligman indicated a precisely contrary result. Winter purchasers were more cautious.

${ }^{\infty}$ Sales for Sale (Jan. 1933), 7 Fortune 72. 


\section{A. Problems of Collection and Adjustment}

Although such defaults seem inconsiderable when compared with total sales, laxity by the company would soon prove a stepping stone to impositions. Y'et the exercise of strict default according to the letter of the contract would be at the cost of consumer and dealer good will. The situation requires the exercise of discriminating judgment. It appears that the finance company will seek to adjust the difficulty or repossess the car within a period of thirty days.

Within a day or two of default in payment, there comes the first of several form letters, courteous but increasingly firm, advising of the overdue payment. If no response is received, a personal contact is usually made where possible. In some cases, where the dealer is working under a repurchase agreement, he himself may do the contacting and help to adjust the difficulty, but more usually the adjuster of the finance company is assigned the burden. The result of the personal visit is either a payment, a promise to pay within a few days, or a refusal, often coupled with the assertion of a supposed defense. Occasionally there is voluntary surrender of the car. A promise to pay or payment ends the difficulty at this time, but acceptance of payment does not preclude declaration of default for non-payment of a subsequent instalment. ${ }^{96}$

More often the buyer finds that he cannot meet the terms of the contract, although able to pay if given more time. In such cases if the finance company is convinced that the buyer is still a good moral risk from a credit standpoint, there may be either a short extension of time on the unpaid instalment or a revision, oral or written, of the credit terms of the contract. ${ }^{97}$ Since the business of the companies is financing, not refinancing, extensions will often be refused, and the purchaser will frequently fall into the hands of one of the so-called refinance companies, which pays off the balance due the finance company and takes over the conditional sale contract and note. Their operation is essentially that of a small loan company, ${ }^{08}$ and at the hands of one of the many unscrupulous operators in this field, the purchaser soon undergoes

${ }^{\infty}$ Pac. Finance \& Inv. Co. v. Pierce, 48 Cal. App. 494, 19r Pac. 1115 (1920).

"T The helplessness of an individual against an unscrupulous creditor holding a valid legal instrument is illustrated in this situation by the practice of racketecring companies which take advantage of inconsequential defaults to scize cars for the sake of obtaining a repossession charge when the purchasers seek their return. The fee usually is based on the size of the equity. Nugent and Henderson, Instalment Selling and the Consumer (1934) I73 ANNaLs 93, 97. The better companies do not resort to this practice of repossessing mercly to extort a repossession fee, when it is contemplated that the contract will be revised cr some other adjustment made. Delinquency charges, however, are sometimes levied. $1 d$. at 98 .

A proposed "Instalment Sales Financing Law" in Massachusctts would practically preclude such skullduggery, by a section providing: "No other charges, bonus, fee, expense, or demand of any nature whatsoever shall be made so long as the buyer fulfills the conditions of the contract; and no fines, penalties, or charges shall be made for delay, delinquency, repossession, refinancing, legal expense or other cause unless such charges are specifically set forth in the contract both as to amount and as to the conditions under which they may be imposed." Mass. Sen. Bill No. 55, \$218 (1935). The Indiana Retail Installment Sales Act of 1935 includes provisions substantially similar in effect. Ind. Acts 1935, H. B. 377, \$\$6, 7.

${ }^{20}$ For a discussion of the operation of the small loan business, see Clark, Financing the Consumer (1931) $25 \mathrm{et}$ seq. 
financial torture which by comparison makes his former relation with the finance company a pleasant one.

When the purchaser in default can be carried no further, the finance company, in the usual case, rather than sue at once for the balance due under the note, resorts to the property.

\section{B. Problems of Repossession}

With a few variations, the contracts provide upon default that:

"Seller or his representative may take possession of said car, and all equipment, accessories or repairs thereon, which shall be considered a component part thereof, wherever it may be found, and may enter any premises therefor without notice or demand to Purchaser and without legal process, and Purchaser waives all claims for damages caused thereby."

To regain possession of the property, apparently there is in general no resort to legal process, the waiver being generally effective.99 In the case of furniture or domestic appliances, a couple of husky movers will be sent after the property, and seldom fail to return with it. ${ }^{100}$ The license to enter upon the premises is generally considered irrevocable, ${ }^{101}$ and in exercising it the vendor may exercise such force as may be necessary. ${ }^{102}$ But in case of resistance, the finance company must, at its peril, stop at the precise point where sufficient force ends and excessive force begins. ${ }^{103}$ However, objections and protests of the conditional purchaser do not make an otherwise rightful retaking wrongful, unless there is a breach of peace committed by the seller's agent. ${ }^{104}$ More generally in the case of automobiles, there will be no entry upon the premises but a "lifting" of the car from the street where the vendee has parked it. ${ }^{105}$ Usually there need be no prior demand for payment ${ }^{106}$ or delivery of the goods unless for some reason, such as a prior waiver of prompt performance, the purchaser is equitably entitled to notice. ${ }^{107}$ In Missouri and Ohio, there can be

" C. I. T. Corp. v. Reevc;, II2 Fla. 424, 150 So. 638 (I933); Sund v. Riggs, 93 Wash. 314 , 160 Pac. 950 (1916).

${ }^{200}$ The abuses which may aaturally arise from entering a person's household. to recover property led to the inclusion in Section 224 of the Massachusetts bill, supra note 97, of a requirement that household goods must be retaken by legal process.

2023 JoNEs, op. cit. supra note $51, \$ 1339$.

102 Lambert v. Robinson, 162 Mass. 34, 37 N. E. 753 (I894); cf. (1935) Ig MiNN. L. Rev. 602.

${ }^{100}$ See v. Automobile Discount Corp., 330 Mo. 906, 50 S. W. (2d) 993 (I932); Gen. Motors Acc. Corp. v. Davis, 15I Okla. 255, 7 P. (2d) I57 (I93I); 3 JoNEs, op. cit. supra note 5I, \$1339.

${ }_{106}$ UNI. CoND. SALES ACT, \$I6 (if goods cannot be retaken without breach of the peace, they shall be retaken by legal process); Bankston v. Hill. I34 Miss. 288, 98 So. 689 (1924); La Porte Motor Co. v. Firemen's Ins. Co., 209 Wis. 307, 245 N. W. 105 (1932); see C. I. T. Corp. v. Reeves, supra note 99.

${ }^{100}$ Such a retaking, even without knowledge of the buyer, is valid. Gen. Motors Ace. Corp. v. Shuey, $243 \mathrm{Ky} \cdot 74,47$ S. W. (2d) 968 (r932).

Io: Estruch, op. cit. supra note 83, \$5369-372; cf. UNI. CoNd. SALES ACT, \$I7 (seller has option of giving notice $20-40$ days before repossession of intention to retake, or of retaking without notice and permitting a ten day redemption period).

${ }^{10 t}$ Pac. Fin. Corp. v. Webster, 16I Wash. 255, 296 Pac. 809 (I931); Peoples Furn. Co. v. Crosby, 57 Neb. 282,77 N. W. 658 (1898). And when there is actually no default, the finance company is liable for conversion, the damages including the buyer's loss of use of the car. Comm. Credit Co. v. Miron, I08 Conn. 524, 143 Atl. 846 (1928). 
no repossession unless prior payments, less a reasonable amount for use and damage, are returned. ${ }^{108}$

When repossession through legal process becomes necessary because of resistance by the buyer or for other reasons, ${ }^{109}$ an action of replevin or of claim and delivery is brought. Apparently such actions are seldom contested, but the costs, ranging approximately from $\$ 2.50$ to $\$ 7.00$, make repossession without such a device more acceptable to the finance company. ${ }^{110}$

Immediately upon repossession there arise problems as to accessories attached to the car and property contained therein. Accessories which belong to the car purchaser pass to the finance company under such a contract provision as the one noted above. ${ }^{111}$ Where title to the accessories has been retained by another conditional seller, recovery will depend on the manner in which they are attached. ${ }^{112}$ As to property in the car, a question arises where there has been repossession without legal process. Foreseeing possible fraudulent claims as to such property, the finance companies make a practice, upon repossession, of immediately removing the car to a garage and there checking the contents with the adjuster and garage employees serving as witnesses. ${ }^{113}$ Usually the property is returned upon request by the purchaser. In one contract there is a requirement of notice by the purchaser within 24 hours after repossession of any claim for articles not included in the repossession statement, with an option in the holder in the absence of such notice "to make such disposition of the property as it shall deem fit."

${ }^{100}$ Under the Missouri statute the amount paid in makes no difference, but the seller is allowed to deduct a reasonable compensation for use of the property which in no case shall exceed 25 per cent of the payment. Mo. Rev. Stat. (1919) $\$ 2285$. The Ohio statute does not require tender unless at least 25 per cent has been paid by the buyer and up to 50 per cent may be deducted as compensation for use. OHIO Gen. CODE (Page, I926) \$8570.

${ }^{100}$ There is prevalent in certain sections of the county a definite "holding up" of finance companies in their efforts to repossess peacefully. This consists in threats of police officers, sometimes accompanied with actual force, to prevent repossession without resort to legal process. Little reason can be found for such obstructions except the desire to obtain fees.

${ }^{110}$ The adjusters of the finance company may follow a delinquent purchaser for several days until an opportune moment for retaking the car appears. This done, there is seldom, if ever, complaint as to the method of retaking.

${ }^{111}$ Lynch v. Sable-Oberteuffer-Peterson, 122 Ore. 597, 260 Pac. 222 (I927).

112 Accessories may be removed if this will not damage the whole car. Motor Credit Co. v. Smith, 18I Ark. 127, 24 S. W. (2d) 974 (1930). Even though the contract provides "that any added or substituted parts, body or equipment, placed upon the car during the life of this agreement . . . shall become a component part thereof," the selier of tires is still entitled to them. Tire Shop v. Peat, 115 Conn. I87, 16r Atl. 96 (1932). The solution to this problem does not depend on recording acts but rather on whether the doctrine of title by accession applics to automobile equipment which is easily removable. The holding of Tire Shop v. Peat, supra, seems sound on the theory that the contract between the automobile dealer and the purchaser can not bind property subsequently acquired, in which another person, not a party to this contract, has reserved a security title. However, conversely, whether the accessories seller may secure a lien on the car for the price of the accessories would depend on the recording acts and the lien statutes. See discussion of garage liens, p. 242, infra.

11 This practice seems to have effectually prevented suits on fraudulent claims, and no cases have been encountered in which the exact problem arose in a civil suit. In Universal Credit Co. v. Wyatt, 56 S. W. (2d) 487 ( $T e x .1933$ ), the buyer claimed $\$ 14$ for damages for property in the car in addition to other damages, but no further mention of the claim is made in the case. In a Kentucky case, an adjuster was held guilty under a statute making it a misdemeanor for one to take property of another without criminal intent. Commonwealth v. Larson, $242 \mathrm{Ky} .317,46 \mathrm{~S}$. W. (2d) 82 (1932). 


\section{Problems of Resale}

Upon repossession of the car, there arises a direct conflict in the interests of the finance company and the purchaser, depending on whether or not the value of the car is greater or less than the unpaid balance. It is in the effect that repossession has on the rights of the parties that the difference in development of the rules applicable to the conditional sale and the chattel mortgage have been most apparent. ${ }^{114}$ Where a mortgaged car had been repossessed by the mortgagee, the mortgagor still had a right to redeem it by paying the sum in default. ${ }^{115}$ If there were no redemption, the mortgagee could sell the car and apply the proceeds to the liquidation of the debt, plus costs of repossession and resale. The mortgagor was entitled to any surplus with a corresponding right in the mortgagee to a decree for any deficiency. ${ }^{118}$ In addition, prior action for the chattel mortgage debt did not bar the subsequent foreclosure of the chattel mortgage. ${ }^{117}$ These equitable principles were not embodied in the law as to conditional sales. Generally, the buyer was permitted no redemption. $^{118}$ On the other hand, if the seller elected to repossess, he was regarded as having rescinded the contract and had no further right to sue the buyer for the unpaid balance, and conversely, if he elected to sue, he was debarred from repossessing the property. ${ }^{119}$ Although the courts talked of rescission, the seller was usually permitted to retain the payments. ${ }^{120}$ Corollary to the denial of suit for a deficiency was a refusal of courts to require the seller to account for any surplus in case of resale. ${ }^{121}$

11' The development in equity of the law of mortgages, the development at law of the law of sales, and the imperfect "procedural coalescence of law and equity" offer a historical explanation of the practical differences existing in the formally similar conditional sale and chattel mortgage. Note (1923) 36 HARV. L. REV. 740.

${ }^{113}$ Before foreclosure or sale, the mortgagor may redeem in equity within a reasonable time, even though such right of redemption is not conferred by statute. Kinkead v. Peet, 153 lowa 199, 132 N. W. 1095 (IgII); Penobscot Produce Co. v. Martin, I28 Me. 386, I47 Atl. 867 (1929); cf. McQuagge v. Thrower, 214 Ala. 582, 108 So. 450 (I920). "This may be regarded as a settled rule in every state whose courts have full equity powers, and where redemption has not been specially provided for by statute." 2 JoNEs, op. cit. supra note 5I, $\$ 85$.

120 "The ground on which equity entertains such a bill is, that the property may be sold under the direction of the courr; that, if it falls short of satisfying the debt, the mortgagee may have a decree for the residue; or, if there should be a surplus, that it may be awarded to the mortgagor, and so put an end to litigation. If the mortgagee should sell, himself, there would be, in case of deficiency, an action at law to recover the remainder of the debt; or, if there should be a surplus, the mortgagor might sue for it. Equity makes an end of these matters." Chancellor Harper in Bryan v. Robert, I Strob. Eq. 334, 343 (S. C. 1847 )

${ }^{212}$ Elder v. Rouse, 15 Wend. 219 (N. Y. 1836).

${ }^{113}$ Burdick, Codifying Conditional Sales Law (1918) I8 CoL. L. REv. 102, I08.

${ }^{110} 2$ WirListon, SALES, $\$ \$ 579,579 a$.

${ }^{20}$ Logically, the seller's act of repossession can be treated as rescission only if he is required to place the buyer in status quo by returning the payments made on the contract, less a reasonable sum for use and damage. See C. W. Raymond Co. v. Kahn, I24 Minn. 426, 429, I45 N. W. I64, I66 (1914). A few states require this. Sce e.g., Pierce v. Staub, 78 Conn. 459, 62 Atl. 760 (1906); Quality Clothes Shop v. Keeney, 57 Ind. App. 500, Io6 N. E. 54I (1914). More properly repossession can be said to be an enforcement, rather than a rescission, of the contract and consequently there is a right to retain payments. Rayfield v. Van Meter, I20 Cal. 416, 52 Pac. 666 (1898); Mohler v. Guest Piano Co., 186 Iowa 161, I72 N. E. 302 (1919); Vold, supra note 56, at 725; Note (1932) I 7 Minn. L. Rev. 66, 70.

${ }_{21} 1$ The theory of the courts which have adhered to this doctrine is that two inconsistent courses are open to the seller, one to recover the goods and disaffirm the contract, the other to bring an action for the 
This doctrine of "election of remedies" worked to the satisfaction neither of instalment sellers nor of buyers, and it has been the object of much criticism by legal commentators. ${ }^{122}$ Gradually, the differences between the conditional sale and the chattel mortgage have been whittled down, in some states by judicial decision and in others by statute. This process has been accelerated, as will be seen, by the contracts generally employed by finance companies.

The Uniform Conditional Sales Act has gone far towards assimilating the law of conditional sales to that of chattel mortgages. In the nine jurisdictions ${ }^{123}$ where it is in effect, the buyer is allowed ten days after repossession in which to redeem by tender of the amount due under the contract at the time of the retaking with interest and the costs of repossession.124 Under proper exercise of the redemption right the purchaser may "continue in the performance of the contract as if no default had occurred." 125 The statement quoted has been held to defeat the operation of the acceleration clause. ${ }^{126}$ A few states which have not adopted the Uniform Act nevertheless have recognized, by statute ${ }^{127}$ or decision, ${ }^{128}$ a right of redemption in the purchaser.

However, even where redemption is permitted, in many cases the property will not be redeemed either because of the buyer's inability to raise the money or his belief that the property is worth less than the balance due. For a fair adjustment of the rights of the parties, there remains the necessity of providing for suit by the seller in case of a deficiency and for payment to the buyer in case of a surplus.

Proceeding, therefore, by analogy, to chattel mortgage law, the Uniform Act as a condition precedent to a suit for a deficiency by the seller requires a resale in com-

price and thus affirm it as a sale. See 2 WiLliston, SALES, \$579. "It is believed that the doctrine of election was in large part the result of the struggles of the law courts, hampered by an inadequate procedure, to do equity between the parties." Note (1929) 29 CoL. L. REv. 960, I123, at 961. This note contains a penetrating study of the doctrine as developed in Massachusetts, California, and Mississippi cases.

122 The criticisms in the main have taken three lines: ( 1 ) By denying the seller the two remedies for which his contract provides, the express intention of the parties is negatived; (2) That the doctrine is often based on the misconception that a conditional sale is an executory contract to sell, when in reality the seller has only retained a security title, which he should be permitted to foreclose; (3) It works a hardship on both parties since it denies the seller the right to sue for a deficiency, and gives no opportunity to the buyer to redeem his interest, which may exceed the balance due. See 2 Williston, SALES, 5579; VoLD, SAIES (1931) \$\$95, 96; Magill, The Legal Advantages and Disadvantages of the Various Methods of Selling Goods on Credit (r922) 8 ConN. L. Q. 2ro, 215-22r.

${ }^{123}$ For the states adopting this act, see note 59, supra.

22 By giving notice in writing, 20 to 40 days in advance, of intention to retake, the seller may eliminate the, right to redeem. UNI. Cond. SALES ACt, 317 .

${ }^{125}$ Id., $\$ 18$.

220 Street v. Comm. Credit Co., 35 Ariz. 479, 28I Pac. 46 (I929); Harlee v. Fed. Finance Corp., 4 W. W. Harr. 345, 152 Atl. 596 (Del. 1930); Cox v. Gen. Motors Acc. Corp., 59 S. D. 588, 241 N. W. 609 (1932).

${ }^{227}$ See, e.g., Minn. Laws (193I) c. 339, 53. In some ten states which require, or permit the buyer to require, resale when a certain amount has been paid in, an opportunity to redeem is in effect secured to the buyer. Commissioners' Note to Uni. Cond. Sales Act, 518,2 U. I. A. (1923) 29.

${ }^{123}$ Perkins v. Skates, 220 Ala. 216, 124 So. 514 (1929); Mercier v. Nashua Buick Co., 84 N. H. 59, I46 Atl. I65 (r929). 
pliance with its rules, and, to protect the buyer against forfeiture in the situation where loss to him is most likely, requires such resale where he has paid more than 50 per cent of the purchase price. ${ }^{129}$ Other statutes of this type also exist in a few states. ${ }^{130}$ Even in states where such statutes do not obtain, the finance companies, to avoid the doctrine of election of remedies, have now quite generally provided in their contracts for such protection ${ }^{131}$ by inclusion of a clause of which the following is typical:

"The property may be sold with or without notice, at public or private sale at which the holder may purchase, and the proceeds, less the expense of taking, removing, holding, repairing and selling the property and less attorney's fees as above provided and the expense of liquidating any claims or liens, shall be credited on the amount unpaid hereunder; or without such sale the fair market value of the property at the time of repossession may be credited upon the amount unpaid; in either event Purchaser agrees to pay the balance forthwith as liquidated damages for the breach of this contract; any surplus shall be paid to the Purchaser."

Such a clause as this is generally held to remove the objection that the seller's repossession has constituted an election of remedies. ${ }^{132}$ Even where such a provision is not present, a number of courts have permitted the conditional seller to treat the reserved title as a lien and to bring proceedings to foreclose it. ${ }^{133}$

In the absence of statute, the contractual provisions governing the manner of resale are generally upheld. ${ }^{134}$ But a number of states have statutory regulations governing such sales, and these may not be waived. ${ }^{135}$ Such statutes generally require a public sale within periods ranging from fifteen to sixty days after retaking. ${ }^{138}$ In compulsory resale under the Uniform Act, the property must be sold at public auction within thirty days after retaking and after ten days' written notice to

10 Uni. Cond. SAres ACT, \$rg. The resale was made compulsory in this situation to protect the rights of small debtors poorly informed as to their status. But the experience with resale has shown that where less than 50 per cent is paid in, the requirement of resale is a useless and expensive formality. Therefore, Section 20 makes resale in the latter situation optional with the parties. The seller need not comply with formalities as to resale in this situation unless he desires to suc for a deficiency. UNI. Cond. SALEs ACT, 523. See Commissioners' Note to $\$ 5 \mathrm{rg}, 20,2$ U. L. A. (I923), 33, 35.

${ }^{100}$ E.g., Tenn. Code (Shannon, I932) $\$ \$ 7287,7292$ (compulsory); Mass. Ans. Laws (1933) c. 255, 513 (optional with buyer; 75 per cent must have been paid in). See Ohio and Missouri statutes, supra note 108, making refund condition precedent to repossession.

$2 \pi$ This clause is in the nature of a general foreclosure clause in a chattel mortgage except that it does not provide for a right of redemption. Chattel mortgage forms, where used, also omit provision for redemption, but the right exists independently of contract or statute. See cases cited supra note II5.

${ }^{219}$ Smith v. Harrington, 41 Idaho 155,238 Pac. 530 (1925); La Salle Finance Co. v. De Jarnet, 95 Ind. App. 468, 18I N. E. I64 (I932); First Nat. Bank v. Yocom, 96 Orc. 438, 189 Pac. 220 (I920). Contra: Nashville Lumber Co. v. Robinson, 9 I Ark. 319, 12 I S. W. 350 (1909). See 3 JoNEs, op. cit. supra note $51, \$ \$ 1311,1327$.

124 VOLD, SAr.ES, $.596 ; 3$ JONES, op. cit. stupra note. $51, \$ 1367$.

${ }^{22}$ Comm. Credit Co. v. Cook, 165 S. C. 394,164 S. E. I7 (1932).

${ }^{216}$ See note 130 , supra. The Uniform Conditional Sales Act, $\$ 26$, prohibits waiver except of certain specified things. The same result has been reached by decision in states having resale statutes. Desseau v. Holmes, 187 Mass. 486,73 N. E. 656 (1905).

19 Commissioners' Note to Uni. Cond. Sales Act, $\$ 19,2$ U. L. A. (1923) 33. 
the buyer. ${ }^{137}$ There is a strict penalty on the seller for failure to comply with these provisions. ${ }^{138}$

It is far from certain that these statutory safeguards always work to the buyer's advantage. A forced sale at public auction at which his creditor may be a bidder is not likely to yield a surplus. This may be true even in a favorable market, ${ }^{139}$ and where demand has fallen off, the buyer's equity is certain to be wiped out.

\section{Interests of Third Persons}

There is a risk of deception to third persons inherent in the delivery of possession of a chattel to a purchaser while the seller retains a security title for payment of the price. Objections to such secret liens usually availed nothing at common law where the doctrine prevailed that a conditional seller or chattel mortgagee could not be deprived of his property in the goods without his consent. ${ }^{140}$ The harshness of such a rule as against those who made expenditures on the strength of the purchaser's apparent ownership inevitably led to the adoption of a device designed to protect third parties, while at the same time preserving the security of the seller. This device is the recording act. Thus, there are now statutes in every state for recordation ${ }^{141}$ of the chattel mortgage, and in most, for recordation of the conditional sale and bailment lease. ${ }^{142}$ These statutes designate a place of registration, ${ }^{143}$ e.g., the county clerk's office, where the contract may be recorded, and specify a certain time within which the contract must be recorded. Persons who wish to buy personal property or lend money on its security may, therefore, ascertain from the records whether there are any prior claims to which the property is subject.

Since there are usually separate recording acts for conditional sales and-chattel

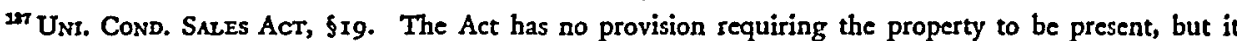
has been held that the common law requirement as to the property being present at the place of sale still prevails. Strickland v. Hare \& Chase, Inc., 217 App. Div. 196, 216 N. Y. Supp. 506 (1926); Comm. Inv. Trust, Inc. v. Browning, 108 W. Va. 585,152 S. E. 10 (1930).

${ }^{288}$ For failure to observe the resale provisions, the seller is liable to the buyer for actual damages, if any, "and in no event less than one-fourth of the sum of all payments which have been made under the contract, with interest." Id. \$25.

220 "The sale of repossessed cars by companies financing used cars is frequently scandalous. . . In some of these auction markets . . . the difficulties of an unknown individual in bidding are reminiscent of the farm foreclosure sales of 1932. Sales of repossessed cars are frequently the happy hunting ground of a closed membership of used car dealers whose objections to intruders might take violent forms. .. These abuses, though exceedingly common, do not apply to instalment selling as a whole." Nugent and Henderson, supra note 97 , at 97.

320 WILLISTON, SALES, $\$ \$ 324,325$.

161 Recordation as used in the above discussion includes filing. Chattel mortgages are more commonly recorded, while filing is generally required for conditional sales. Hanna, Cases and Materials on SECURITY (I932) 323, 324.

${ }_{12}$ Thirty-five states require the recording of conditional sales of personal property, but, in every jurisdiction, chattel mortgages of certain types of personalty must be recorded, if the mortgagor retains possession. Bailment leases are generally held to be subject to the recording requirements for conditional sales, except in Pennsylvania, where no recording of the bailment lease is required. The recording statutes of the states are analyzed and their variations indicated in HaNNA, op. cit. supra note I4I, at 312-327.

${ }_{13}$ The county almost universally is the unit constituting a recording district, but the statutes vary as to whether recording is to be determined by the situs of the property or the residence of the buyer or seller, or both situs and residence. Id. at 320-323. 
mortgages, the requirements of which vary from state to state and even within a state, no extended discussion of the effect of such recording requirements can be attempted here.14 However, several generalizations may be made. In the first place, persons with notice of the seller's interests are not entitled to attack a transaction which has not been recorded. ${ }^{145}$ In addition, almost all of the acts protect only persons who have given value. ${ }^{140}$ Subpurchasers and creditors are the usual classes protected, ${ }^{147}$ but most acts include only those creditors who have reduced their claims to judgment, acquiring liens by attachment or levy. ${ }^{148}$ Some statutes protect subsequent mortgagees. Under the Igro amendment to the National Bankruptcy Act, a trustee in bankruptcy of the purchaser is accorded the status of a lien creditor and will therefore prevail against a finance company which has not recorded its contract. 149 However, recording of the contract or the retaking of the car within four months of bankruptcy is not a preference, and the finance company's interest will be preserved. ${ }^{150}$ In case of receivership, the receiver is generally accorded no lien because of his position as receiver. ${ }^{151}$ In practically every state the requirement that the contract must be recorded within a certain period of time is regarded as giving a grace period within which the finance company is protected in the absence of recordation, and recordation after its expiration is effective as against parties whose claims accrue subsequently to such recordation. ${ }^{152}$

The mobility of chattels in general and the automobile in particular has led to a problem not presented under real property recording acts, where a search of the records in the recording district in which the land is located will generally reveal the owner's interest in the property. But once a car has been removed from the record-

${ }^{14}$ Although recording for conditional sales developed subsequent to the requirement of this formality for chattel mortgages, it might be supposed that the statutory requirements would be the same. A striking example of the fallacy of such an assumption is furnished by New York, where an unfiled conditional sale is invalid against purchasers or lien creditors, while an unrecorded chattel mortgage is invalid against general creditors: N. Y. Cons. Laws (Cahill, 1930) c. 34, \$230, c. 42, \$65.

${ }^{145}$ Estrich, op. cit. supra note $83, \$ 199$. Recording serves as constructive notive, but what constitutes notice in the absence of such recording is difficult of decision. Bocert, op. cit. supra note 67 , at 80 . In at least one state, North Carolina, "no notice, however full and formal, will supply the place of registration." See North State Pian's Co. v. Spruill, 150 N. C. 168, 169, 63 S. E. 723, 724 (1909).

116 "Just what is meant by 'value,' however, is not always susceptible of exact definition, and each case must be largely its own criterion, to be determined upon its own facts. The payment of money, of course, is value, as is the surrender of other property." Jones, op. cit. supra note 51, $\$$ Iag8.

${ }^{217}$ For a discussion of the persons protected by recording statutes, see EsTRICh, op. cit. supra note 83 , 55168-177.

${ }^{14}$ Vold, supra note 56 , at 731 . Some states, however, recognize general creditors, varying as to whether the credit need be extended subsequent to the transaction. The like variation exists as to lien creditors. The cases are collected in BogerT, op. cit. supra note 67, at 8I-88.

${ }^{160} 36$ STAT. 840 (Igro); II U. S. C. A. $\$ 75$ (a) (2). Under this amendment, wherever lien creditors are made superior to the finance company because of failure to record, the trustee will prevail. Jones, op. cit. supra note 51, \$II 43 .

${ }^{100}$ Bailey v. Baker Ice Machine Co., 239 U. S. 268 (1915) (recording); In re Johnson, 282 Fed. 273 (W. D. Iowa, 1922) (retaking).

ivi Quinn v. Bancroft-Jones, I8 F. (2d) 727 (C. C. A. 2d, I927); Delaware Trust Co. v. Elder, I2 Del. Ch. 263 , II2 Atl. 370 (1920).

168 Comm. Credit Co. v. Gaiser, 134 Kans. 552, 7 Pac. (2d) 527 (I932); Morey \& Co. v. Schaad, 98 N. J. L. 799, 121 Atl. 622 (1923); Motor Exchange Co. v. Comm. Inv. Co., 15I Okla. I76, 3 Pac. (2d) 178 (193I); Bent v. Weaver, 106 W. V2. 164, I45 S. E. 594 (1928). 
ing district, a search of the records in the state to which it has been taken will reveal nothing to the prospective purchaser or lender. Generally the rule is that the finance company is protected against such third parties until it has actual notice of the removal and time to record again. ${ }^{163}$ In some states, where a desire to protect residents is paramount, the company is held subordinated to the claim of an innocent third party. ${ }^{154}$ Although this minority view has been criticized, ${ }^{155}$ it is not without some justification. The finance company has placed it within the power of the purchaser to move the property from place to place, despite the contractual prohibition against his doing so. In determining whether or not the finance company should be protected as against third parties, three considerations must be weighed: (r) the relative severity of the loss of the subpurchaser or creditor as compared with that of the finance company which can insure itself against such risks; (2) the fact that car purchasers and creditors actually seldom do consult the records; and (3) the risk that failure to recognize the finance company's title would materially augment the number of "skip" cases by facilitating the disposal of wrongfully removed cars.

Even in the state of sale, the large finance company generally does not record unless the transaction is over $\$ 500$. Although the fees are small, the number of transactions, together with the relative infrequency of claims by third parties, makes it more economical to set up a reserve against such losses where a third party prevails because of failure to record.

In many jurisdictions, certain liens are occasionally created by statute, generally for the protection of landlords and garage owners or mechanics. These statutory liens have occasionally been seriously abused, especially in the case of garage liens. A purchaser about to default will turn the car over to a garage which will put in an exorbitant bill for repairs or storage, ${ }^{156}$ perhaps sufficient to cover the buyer's equity. Under some statutes mechanics' liens are given priority in full or to a certain amount even though the finance company has recorded. In states where the statutes are silent as to the priority of the mechanic's lien, a majority of courts refuse to sanction the extension of the favored position of the lienor, and subordinate his claim to that of the finance company, unless it has consented to the repairs. ${ }^{157}$

${ }^{200}$ Mercantile Acc. Corp. v. Frank, 203 Cal. 483, 265 Pac. 190 (1928); Goetschius v. Brightman, 245 N. Y. 186,156 N. E. 660 (1927); JoNes, op. cit. supra note 51, \$\$1149-1161. Section I4 of the Uniform Conditional Sales Act provides for refiling within ten days after notice of removal. The removal must be permanent. Hare \& Chase, Inc. v. Tomkinson, ro2 N. J. L. 499, 129 Atl. 396 (1925); Forgan v. Smedal, 203 Wis. 564, 234 N. W. 896 (I93I).

ist Wilziston, SAles, \$339; Note (1928) 4r Harv. L. Rev. 779.

155 "The operation of the Texas doctrine illustrates its inconvenience. It appears to be a regular course of business for a swindler to buy a motor car on credit in California, or elsewhere, drive it into Texas, and sell or pledge it there. The original seller is helpless in the face of this practice; and Texas will doubtless continue full of willing bona fide buyers." Beale, Jurisdiction Over Title of Absent Owner in a Chattel, (r927) 40 Harv. L. Rev. 805, at 8ro.

Ise There seems to be no distinction made between a lien for repairs or for storage. Wolfman Co. v. Eisenberg, II 6 Misc. 43, I90 N. Y. Supp. 259 (1921).

${ }^{15}$ For a discussion of this problem, see Note (1927) 40 HARv. L. Rev. 762. Cases are collected in Notes (I922) 20 A. L. R. 249, (I924) 30 A. L. R. 1227. The cases denying the mechanic's lien a priority when the finance company has recorded do not agree where there has been a failure to record. 
The landlord's lien is more usually encountered in respect to the dealer, who is keeping cars in storage, than to the purchaser, whose car is on the street much of the time. While on the street it is not subject to the landlord's lien and may be repossessed. In the absence of statutory priority, the landlord, as in the case of mechanics' liens, will not generally prevail even though the finance company has failed to record. ${ }^{158}$

A perplexing problem is posed by the conditional sale of goods which are to be attached to realty in such manner as to fall within the legal category of fixtures. ${ }^{159}$ If the realty is subsequently sold or mortgaged, will the reservation of title in the conditional seller prevail as against the claim of the buyer or mortgagee of the realty? If the latter has notice of the conditional seller's claim, the reservation will be protected, but as to whether recording of the conditional sales interest gives such notice and as to the effect of lack of notice, the decisions are in conflict. ${ }^{100}$

Certainly the recording acts have not fulfilled adequately an avowed intention on the part of their draftsmen to protect innocent third parties as well as the security interest of the seller or finance company. As to the automobile, a potential answer to most of the difficulties lies in a systematized use of the certificate of title now pravided for in some states under motor vehicle registration acts. In almost every state where adopted, these acts are held to be aimed merely at prevention of theft rather than to serve the purpose of a recording act. ${ }^{161}$ In some states, however, the inscription of the lien or encumbrance on the certificate of title and its retention by the seller affords protection against creditors and purchasers. ${ }^{162}$ With this certificate of title goes a registration certificate to be carried by the purchaser, which indicates his rightful possession, an aid to checking stolen cars. The certificate of title system, if uniformly adopted throughout the United States, with provision for recording the lien or encumbrance on the certificate to be retained by the seller (or finance company) until payment, would constitute an easy method whereby prospective subpurchasers or creditors could ascertain immediately whether the possessor's title was unencumbered. . In addition to keeping a record of car owners, the liens should also be listed by the state department issuing the certificate, assuring a check on the issuance of duplicate title certificates, supplementing the existing criminal provisions which, though stringent, mean little to the dishonest car purchaser.

Under the broad language of a few recording acts, the mechanic's lien would be protected. Jones, op. cit. supra note 51, \$1122.

${ }^{158}$ Snyder v. Collins, 184 Iowa I22, I64 N. W. 624 (I9r7); Comm. Credit Co. v. Vineis, 98 N. J. L. 376, I20 Atl. 417 (1923) Beebe v. Fouse, 27 N. M. ${ }^{194, ~ I 99 ~ P a c . ~} 364$ (r921). See, in general, (1935) 3 Duke B. Ass's J. 27.

150 What constitutes a fixture is a question which has been productive of much litigation. The goods must be so attached to the realty as "to become a part thereof," to use the phrase employed in Section 7 of the Uniform Act, but they must remain "severable without material injury to the freehold." If the goods are not so severable, the attempted reservation of title fails.

${ }^{100}$ For a discussion of this problem, see Bocert, op. cit. supra note 67 , at 97-107.

101 Note (1932) 8 Notre Dame Lawy. 97.

${ }^{100}$ See, e.g., VA. CODE (Michic, 1930) $\$ 2154$ (39) 1. 